\title{
A Holocene Perspective on Algal Mercury Scavenging to Sediments of an Arctic Lake
}

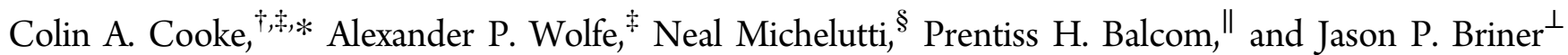

${ }^{\dagger}$ Department of Geology and Geophysics, Yale University, New Haven, Connecticut 06520-8109, United States

${ }^{\ddagger}$ Department of Earth and Atmospheric Sciences, University of Alberta, Edmonton, Alberta, T6G 2E3, Canada

${ }^{\S}$ Department of Biology, Queen's University, Kingston, Ontario, K7L 3N6, Canada

"Department of Marine Sciences, University of Connecticut, Groton, Connecticut 06340, United States

${ }^{\perp}$ Department of Geology, University at Buffalo, Buffalo, New York 14260, United States

\section{Supporting Information}

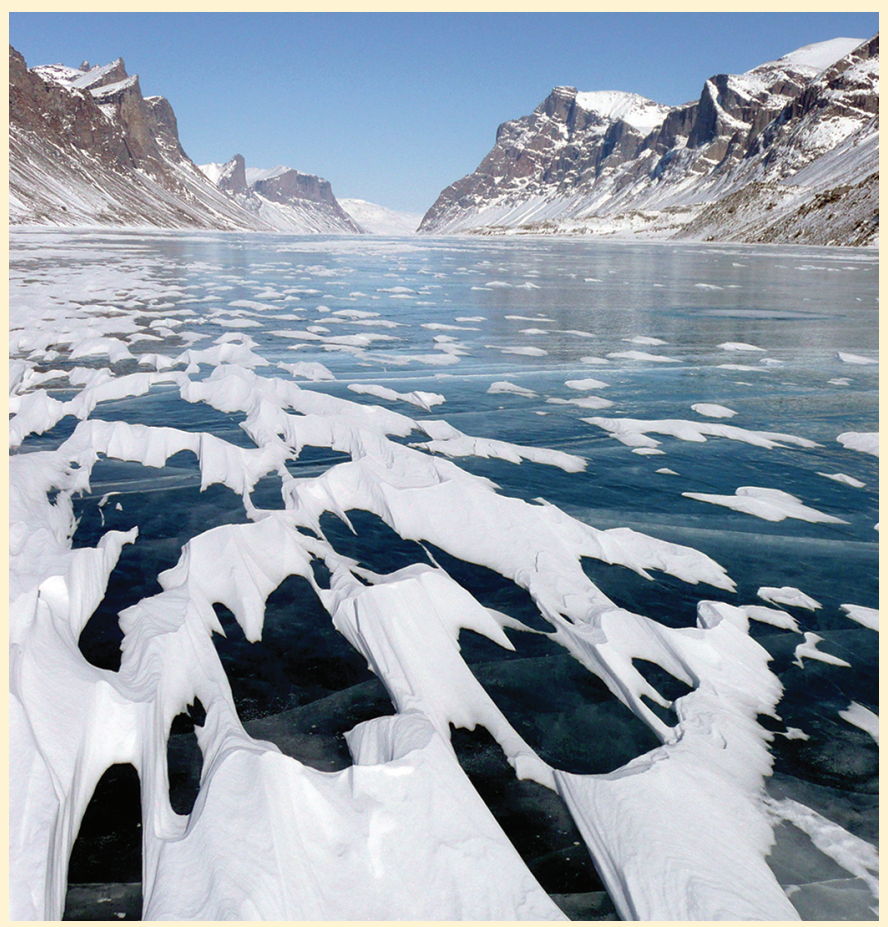

ABSTRACT: Anthropogenic activities have increased the amount of mercury $(\mathrm{Hg})$ transported atmospherically to the Arctic. At the same time, recent climate warming is altering the limnology of arctic lakes and ponds, including increases in aquatic primary production. It has been hypothesized that climate-driven increases in aquatic production have enhanced $\mathrm{Hg}$ scavenging from the water column, and that this mechanism may account for much of the recent rise in lake sediment $\mathrm{Hg}$. Here, we test the relationship between climate, algal production, and sediment $\mathrm{Hg}$ using a well-dated and multiproxy lake sediment record spanning the Holocene from Lake CF3 (Baffin Island, Nunavut, Canada). During the early Holocene, peak (summer) insolation drove July air temperatures higher than present, and resulted in increased autochthonous primary production as recorded by total organic matter, spectrally inferred Chl- $a$, diatom abundance, and carbon stable isotopic signatures. However, there are no relationships between any of these proxies and sediment $\mathrm{Hg}$ concentrations during this interval. Given that the behavior of preindustrial $\mathrm{Hg}$ was relatively stable during past intervals of naturally mediated high production, we surmise that postindustrial increases in $\mathrm{Hg}$ accumulation within $\mathrm{CF} 3$ reflect a multiplicative effect of atmospheric deposition of anthropogenic $\mathrm{Hg}$ and increased sedimentation rates.

\section{INTRODUCTION}

There is ongoing concern regarding mercury $(\mathrm{Hg})$ burdens within food-webs and ecosystems of the Arctic. ${ }^{1}$ Anthropogenic activities emit $\mathrm{Hg}$ to the atmosphere primarily as gaseous
Received: October 3, 2011

Revised: $\quad$ May 16, 2012

Accepted: May 30, 2012

Published: June 11, 2012 


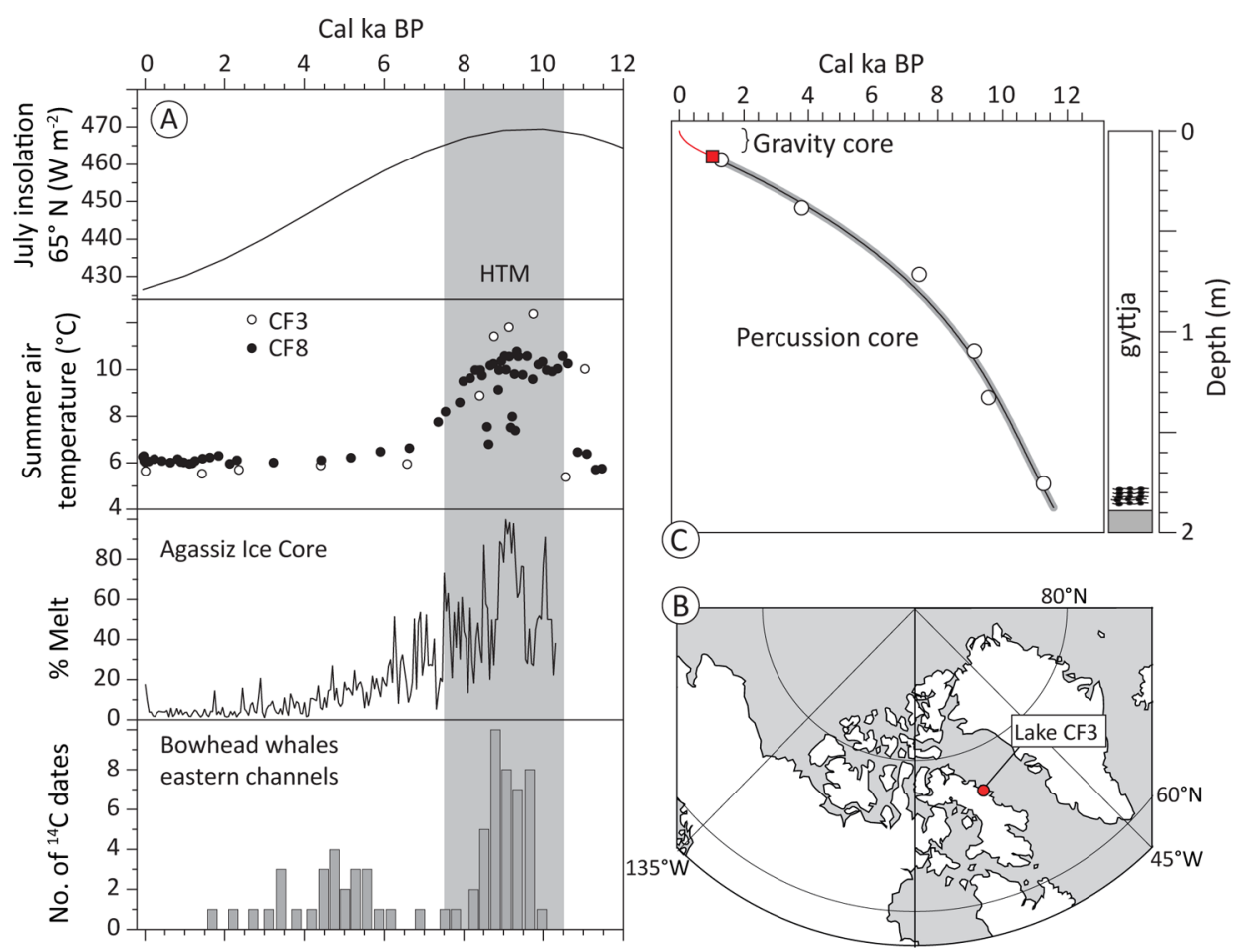

Figure 1. (a) Paleoclimate records from the Baffin Bay region including summer (July) insolation at $65^{\circ} \mathrm{N},{ }^{42}$ chironomid based summer air temperature reconstructions from lakes $\mathrm{CF} 3^{23}$ and $\mathrm{CF} 8,{ }^{22}$ percent melt record from the Agassiz Ice Cap on Ellesmere Island, ${ }^{24}$ and the frequency distribution of ${ }^{14} \mathrm{C}$ dated bowhead whales in the eastern channels. ${ }^{25}$ (b) Map of northern North America showing location of the study site on eastern Baffin Island. (c) Down-core chronology and sediment stratigraphy for Lake CF3. Sediment lithology, which is gyttja overlying approximately $15 \mathrm{~cm}$ of compacted bryophytes and a similar thickness of deglacial inorganic sediment, is shown alongside the composite age-depth model for the Lake CF3 gravity (red line) and percussion cores (black line). The age-depth model was constructed using the clam software package, ${ }^{32}$ and incorporates ${ }^{210} \mathrm{~Pb}$-derived CRS dates, AMS ${ }^{14} \mathrm{C}$ dates on the surface gravity core (red square), and ${ }^{14} \mathrm{C}$ dates on the percussion core (white circles); the gray area represents the $95 \%$ confidence interval for the age-depth model.

elemental $\mathrm{Hg}\left(\mathrm{Hg}^{0}\right)$, which, because of its long atmospheric residence time $(0.5-2$ years $){ }^{2}$ is hemispherically dispersed. Despite a reduction in North American and European $\mathrm{Hg}$ emissions over the past two decades, ${ }^{3}$ and the low rates of atmospheric $\mathrm{Hg}$ deposition in the Arctic relative to lower latitudes, $\mathrm{Hg}$ concentrations in marine mammals remain an order-of-magnitude above preindustrial levels. ${ }^{4,5}$ Most lakesediment cores collected from across the Arctic suggest a 2- to 12-fold increase in $\mathrm{Hg}$ deposition since $1850-1900 \mathrm{AD},{ }^{6-10}$ testifying to efficient northward dispersion of $\mathrm{Hg}$ pollution.

The underlying paradox between sustained enrichments in natural archives (sediment, tissue) in the Arctic despite declining $\mathrm{Hg}$ emissions in the Arctic remains under debate. It has been hypothesized that climate warming may amplify $\mathrm{Hg}$ sequestration to arctic lake sediments due to sorption to organic matter associated with enhanced aquatic primary production, referred to here as the "algal scavenging hypothesis". ${ }^{11-14}$ Indeed, recent increases in primary production are widespread in lakes across the Arctic, and are believed to largely reflect the limnological consequences of climate warming. ${ }^{15}$ The algal scavenging hypothesis suggests that as much as $70 \%$ of the recent increase in sediment $[\mathrm{Hg}]$ can be explained by $\mathrm{Hg}$ sorption to extracellular polymeric substances and cosedimentation with cells of algae such as diatoms. Strong linear correlations between algal-derived organic carbon and $\mathrm{Hg}$ in lake sediment are thought to depict a causal relationship between aquatic primary production and the efficacy of $\mathrm{Hg}$ sequestration.
Kirk et al. $^{16}$ tested the algal scavenging hypothesis by comparing subfossil algal communities and $[\mathrm{Hg}]$ in a series of ${ }^{210} \mathrm{~Pb}$-dated Arctic lake sediment cores. They found little support for the algal scavenging hypothesis and concluded that processes associated with algal production and sedimentation do not govern $\mathrm{Hg}$ supply to lake sediments (though see the comment ref 17 and the subsequent reply by ref 18). In contrast, Jiang et al. ${ }^{19}$ reported a positive relationship between recent warming-driven increases in aquatic primary and $\mathrm{Hg}$ accumulation in a lake sediment core from Ny-Ålesund, Svalbard. Further testing of this hypothesis is warranted because of its relevance for understanding $\mathrm{Hg}$ cycling in the context of northern pollutants and associated policy issues.

A limitation of many previous studies is that they largely rely on short sediment cores dated using ${ }^{210} \mathrm{~Pb}$ geochronology. While ${ }^{210} \mathrm{~Pb}$ dating is the ideal geochronometer for dating sediments deposited over the past $\sim 150$ years, focusing on the industrial era complicates the distinction between processes mediated by climate change and those associated with anthropogenic $\mathrm{Hg}$ emissions because they have considerable temporal overlap. Furthermore, accurate dating of sediments that predate the exhaustion of supported ${ }^{210} \mathrm{~Pb}$, typically using accelerator mass spectrometry (AMS) ${ }^{14} \mathrm{C}$ dating of suitable targets, appears necessary to define accurate $\mathrm{Hg}$ accumulation histories from lake sediments. ${ }^{10}$

The magnitude of recent warming in the Arctic may not yet exceed early-Holocene summer temperatures. ${ }^{20}$ On the east coast of Baffin Island, lake sediment cores, ${ }^{21-23}$ ice cores, ${ }^{24}$ and marine fossil remains ${ }^{25}$ suggest warmer-than-present summer 

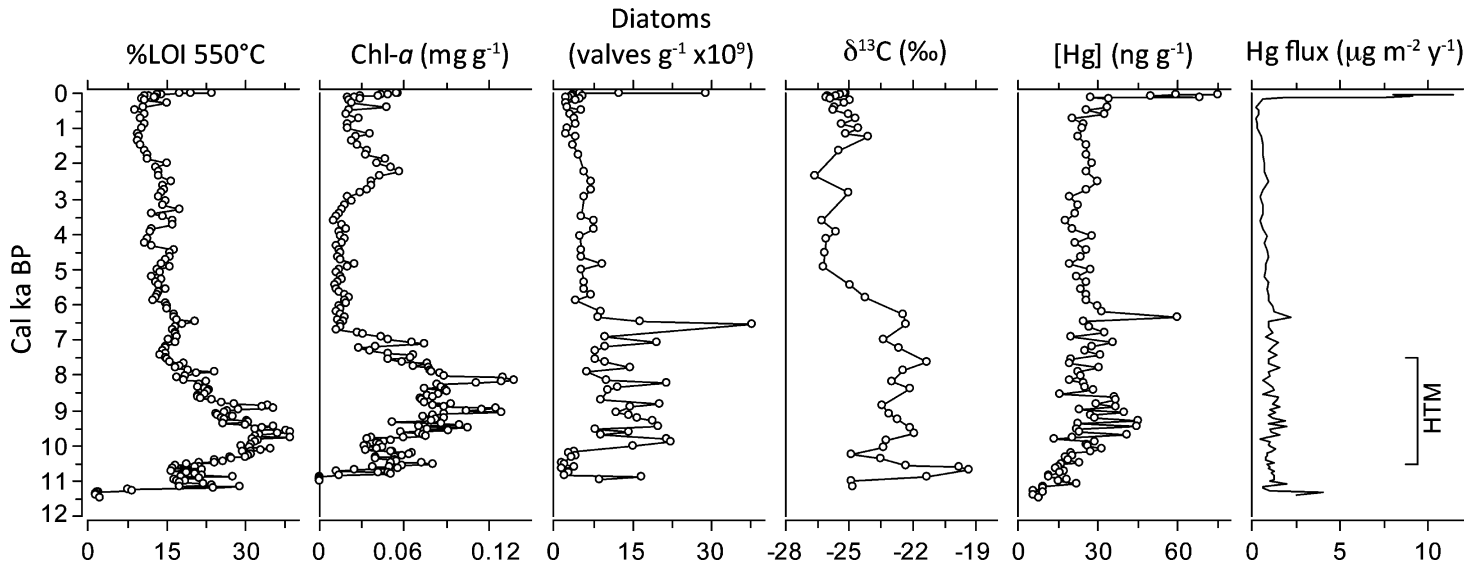

Figure 2. Holocene profiles of past organic matter quantity and quality plotted alongside Hg. Variables include oxidizable organic matter (\% LOI $550{ }^{\circ} \mathrm{C}$ ), spectrally inferred Chl- $a,{ }^{31}$ diatom concentration, $\delta^{13} \mathrm{C}$ of total organic carbon, $[\mathrm{Hg}]$, and $\mathrm{Hg}$ accumulation rate (flux) plotted against age. The Holocene Thermal Maximum (HTM) is also indicated, the timing of which is based upon peak warmth as reconstructed by Chironomidinferred July air temperature from the same sediment core employed for this study. ${ }^{23}$.

conditions during the early to middle Holocene, a period referred to as the Holocene Thermal Maximum (HTM; Figure 1a). Although the timing of the HTM varies spatially, on northeastern Baffin Island its strongest expressions are recorded between about 7.5 and $10.5 \mathrm{ka} \mathrm{BP}\left(\mathrm{ka}=10^{3} \mathrm{cal} \mathrm{yr} \mathrm{BP;} \mathrm{cal} \mathrm{yr} \mathrm{BP}\right.$ = calibrated years before $\mathrm{AD} 1950$ ), which corresponds to peak summer time insolation for the region. The HTM is often associated with clear increases in aquatic primary production and distinct shifts in algal community assemblages. ${ }^{20,21,23,26}$ Well-dated sediment records spanning the HTM therefore offer a unique natural test of the algal scavenging hypothesis, in the absence of confounding anthropogenic influences. Here we present the results of one such test using a well-dated sediment record from Lake CF3, located on the east coast of Baffin Island, Canada. The Lake CF3 sediment record spans continuously the past $\sim 11.5 \mathrm{ka} \mathrm{BP}$ and comprises spliced gravity and percussion cores that have been independently dated. Our goal is to compare the Holocene $\mathrm{Hg}$ record from this locality with parallel records of lake paleoproduction in order to (1) test further the algal scavenging hypothesis; and (2) provide a new benchmark for natural $\mathrm{Hg}$ variability which informs the consideration of recent trends.

\section{MATERIALS AND METHODS}

Study Site. Lake CF3 (informal name) is located on the east coast of Baffin Island, Nunavut, Canada $\left(70^{\circ} 31^{\prime} \mathrm{N}, 68^{\circ}\right.$ $22^{\mathrm{W}} \mathrm{W}$; $27 \mathrm{~m}$ asl) (Figure $\left.1 \mathrm{~b}\right)$. The lake is small $\left(0.2 \mathrm{~km}^{2}\right)$ and shallow $\left(Z_{\max }=7 \mathrm{~m}\right)$, occupying a tundra catchment of $0.6 \mathrm{~km}^{2}$ with little local relief. The lake experiences prolonged ice cover, with the ice-free season currently lasting only 2 or 3 months each year. Limnologically, Lake CF3 is similar to other lakes on the east coast of Baffin Island that are characterized by oligotrophic, highly dilute, slightly acidic water. ${ }^{15}$ Prostrate dwarf-shrub tundra vegetation (Salix, Cassiope, and Empetrum), which is generally snow-covered for at least nine months each year (October-June), surrounds the lake.

Core Stratigraphy and Chronology. New sediment geochemical analyses were undertaken on the same cores first described by Briner et al. ${ }^{23}$ The sediment stratigraphy is a composite of two cores: a $21 \mathrm{~cm}$ gravity core capturing an intact mud-water interface ${ }^{27}$ and a $180 \mathrm{~cm}$ percussion core. $^{28}$ An age-depth chronology for the cores was constructed using excess ${ }^{210} \mathrm{~Pb}$ activities coupled to AMS ${ }^{14} \mathrm{C}$ ages on bryophyte macrofossils. Bryophytes equilibrate reliably with atmospheric ${ }^{14} \mathrm{CO}_{2}$ in the study region, ${ }^{29}$ and thus represent a reliable target for ${ }^{14} \mathrm{C}$ dating in these systems.

Sediment Processing and Data Analyses. Measurement of total $[\mathrm{Hg}]$ was undertaken using a DMA80 direct mercury analyzer at the University of Connecticut, Department of Marine Sciences. ${ }^{30}$ Standard reference materials included in each run were within certified values and the relative percent difference between duplicate measurements $(n=12)$ was $<5 \%$. Mercury data are considered alongside a suite of additional proxies including: loss-on-ignition (\%LOI $550{ }^{\circ} \mathrm{C}$ ), spectrally inferred chlorophyll $a$ (Chl-a), ${ }^{31}$ diatom concentrations, and the $\delta^{13} \mathrm{C}$ ratio of total organic carbon, which collectively provide information about sediment composition, aquatic primary production, and regional paleoenvironmental conditions. $^{20}$

\section{RESULTS AND DISCUSSION}

Core Stratigraphy and Chronology. The CF3 sediment record is composed of $180 \mathrm{~cm}$ of gyttja underlain by a $\sim 15 \mathrm{~cm}$ mat of compacted bryophytes and a similar tickness of deglacial inorganic sediment (Figure 1c). The uppermost intervals of the gravity core, which preserves an intact sediment-water interface, were dated using ${ }^{210} \mathrm{~Pb}$ (Supporting Information (SI) Figure S1). It was then spliced with the longer percussion core on the basis of their respective ${ }^{14} \mathrm{C}$ chronologies (Figure 1c). A composite age-depth model was generated using the clam software package. ${ }^{32}$ Both linear accumulation rate $(\mathrm{cm}$ $\left.\mathrm{y}^{-1}\right)$ and dry mass sedimentation rate $\left(\mathrm{g} \mathrm{cm}^{-2} \mathrm{yr}^{-1}\right.$ ) (SI Figure S2) display large increases in the uppermost sediments, a recurrent feature in sediment cores from eastern Baffin Island lakes (e.g., ref ${ }^{33}$ ). Higher-than-modern dry mass sedimentation rates are noted in the earliest, moss-rich sediments, when macrophyte mats formed effective sediment traps ${ }^{34}$ that accelerated the accumulation of fine-grained material during the first millennium of the record $(11.5-10.5 \mathrm{ka})$.

Sediment Geochemistry. During the Holocene, $[\mathrm{Hg}]$ is lowest $\left(5 \mathrm{ng} \mathrm{g}^{-1}\right.$ ) immediately following deglaciation, but increases gradually to $\sim 30 \mathrm{ng} \mathrm{g}^{-1}$ between 9.5 and $8.5 \mathrm{ka} \mathrm{BP}$ (Figure 2). [Hg] subsequently declines to $25 \mathrm{ng} \mathrm{g}^{-1}$ by $\sim 1 \mathrm{ka}$ $\mathrm{BP}$. In the upper-most sediments, a rapid increase in $[\mathrm{Hg}]$ is initiated $\sim 1900 \mathrm{AD}$, and $\mathrm{Hg}$ concentrations reach $75 \mathrm{ng} \mathrm{g}^{-1}$ during the mid-1970s (the most recent interval measured). A 


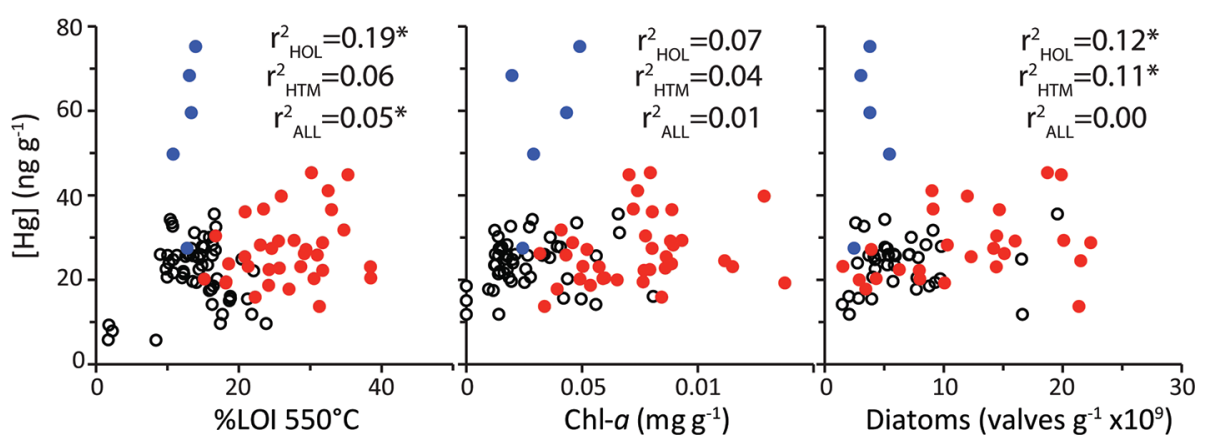

Figure 3. Regression plots between $[\mathrm{Hg}]$ and various proxies of aquatic paleo-production: (a) loss-on-ignition; (b) spectrally inferred Chl- $a$ concentrrations, and (c) diatom valve concentrations. 20th-century data are indicated in blue; HTM samples are in red, and remaining early- and late-Holocene samples are in white. The strength and significance of three analyses conducted using the Holocene data $\left(r_{\mathrm{HOL}}^{2}\right.$; not including the 20th-century data), only the HTM data $\left(r_{\text {HTM }}^{2}\right)$, and all of the data $\left(r_{\text {ALL }}^{2}\right)$ are also indicated $(* 0.05>p<0.10)$.

brief spike in $[\mathrm{Hg}]$ occurs $\sim 6.3 \mathrm{ka} \mathrm{BP}$ and separates the early Holocene, when $[\mathrm{Hg}]$ values are more variable, from the middle and late Holocene, when $[\mathrm{Hg}]$ is less variable.

Calculations of $\mathrm{Hg}$ accumulation rate (flux) reveal little change in the rate of $\mathrm{Hg}$ delivery to $\mathrm{CF} 3$ sediment over time (Figure 2). $\mathrm{Hg}$ flux remains near or below $1 \mu \mathrm{g} \mathrm{m}^{-2} \mathrm{yr}^{-1}$ for much of the Holocene, and as with $[\mathrm{Hg}], \mathrm{Hg}$ flux is more variable prior to $\sim 6 \mathrm{ka} \mathrm{BP.} \mathrm{Hg}$ flux gradually declines over the Holocene, but this trend is reversed by a rapid increase after $\sim 1800 \mathrm{AD}$, when $\mathrm{Hg}$ flux rises to $12 \mu \mathrm{g} \mathrm{m}^{-2} \mathrm{yr}^{-1}$ by $\sim 1970$.

Despite a relatively stable Holocene $\mathrm{Hg}$ profile, CF3 sediment records large-scale shifts in organic matter content and aquatic primary production over the Holocene (Figure 2). Profiles of LOI, Chl- $a$, diatom concentration, and $\delta^{13} \mathrm{C}$ largely parallel each other, recording an early Holocene maximum between 10 and $7 \mathrm{ka}$ BP, followed by a progressive decline. In the case of diatom concentrations, the transition to low diatom abundance during the middle Holocene is abrupt, while LOI and Chl- $a$ record more gradual declines. The $\delta^{13} \mathrm{C}$ signature of organic matter is isotopically enriched until $\sim 6 \mathrm{ka} \mathrm{BP}$ (mean value $\sim-23 \%$ ), and subsequently becomes increasingly depleted. During the HTM, increased within-lake primary production led to greater photosynthetic drawdown of the dissolved inorganic carbon (DIC) pool, thereby reducing the ability of autotrophs to physiologically fractionate against the heavy isotope. ${ }^{35}$ Considered collectively, the largely parallel trends observed in LOI, Chl-a, diatom abundance, and $\delta^{13} \mathrm{C}$ suggest that within-lake primary production governs organic matter supply to CF3 sediment, a conclusion which has been noted repeatedly in other ultraoligotrophic Baffin Island lakes. $^{21,23,26}$

Aquatic Paleo-Production and $\mathrm{Hg}$ Sequestration. Lacustrine, marine, and ice-core proxies reveal a broadly coherent pattern of Holocene climate change within the Baffin Bay region (Figure 1a). Maximum postglacial warmth occurred between 10 and $7 \mathrm{ka} \mathrm{BP}$, and was followed by progressive cooling culminating in Neoglaciation and ultimately the Little Ice Age (1450-1850 A.D.). Early Holocene summer warmth is captured by several independent proxies, including the amount of melt on the summit of ice caps, ${ }^{24}$ decreases of sea ice that allowed range expansions of large cetaceans, ${ }^{25}$ and the isotopic signature of chitin from chironomid larvae in lake sediments. ${ }^{36}$

A clear and consistent early Holocene warming signal is similarly preserved within Lake CF3 sediment. Reconstructions of summer temperature using chironomid faunal assemblages, obtained from the same sediment cores employed here, reveal pronounced summer HTM warming by perhaps as much as 4$6{ }^{\circ} \mathrm{C}$ greater than present ${ }^{23}$ (Figure 1a). LOI, Chl- $a$, diatom concentration, and $\delta^{13} \mathrm{C}$ profiles consistently record early Holocene increases that coincide with this peak summer time warming. The generally synchronous trends among these proxies imply that they record faithfully changes in lake primary production.

However, increases in primary production during the early Holocene appear to have exerted little influence on $\mathrm{Hg}$ accumulation within $\mathrm{CF} 3$ sediment. While $[\mathrm{Hg}]$ does increase to some degree during the early Holocene, $\mathrm{Hg}$ flux steadily declines. In contrast, accumulation rates of Chl- $a$ and diatoms amplify the difference between the early- to mid- and late Holocene (SI Figure S3). Moreover, there is no consistent relationship between $[\mathrm{Hg}]$ and any of the paleoproduction variables measured here (Figure 3). Thus, the sediment record from Lake CF3 does not support the hypothesis that increased algal production stimulated by warming enhanced $\mathrm{Hg}$ sequestration. Instead, $\mathrm{Hg}$ accumulation rates appear to have remained relatively stable over the Holocene in the rage of 0.5$1.0 \mu \mathrm{g} \mathrm{m}^{-2} \mathrm{yr}^{-1}$, with a slight secular decline over time.

Previous studies have also sought to examine the relationship between changes in aquatic primary production and $\mathrm{Hg}$ accumulation. In a series of publications by Outridge and colleagues, ${ }^{11-14}$ positive correlations between $\mathrm{Hg}$ and aquatic primary production (reconstructed by Rock-Eval analysis and diatom abundance) have been reported from six lakes. RockEval is used to distinguish between the S2, or algal-derived, fraction of lake sediment organic carbon, and more refractory forms. In contrast, Kirk et al. ${ }^{16}$ analyzed $\mathrm{Hg}$ and S2 in sediment cores from 14 Arctic and subarctic lakes. They found a significant and positive relationship between $\mathrm{S} 2$ and $[\mathrm{Hg}]$ in eight of the 14 lake cores analyzed. However, in most cases, this positive relationship between $\mathrm{S} 2$ and $[\mathrm{Hg}]$ appears to be influenced by preferential postdepositional degradation of the S2 fraction. Kirk et al. also observed no relationship between S2 and diatom abundance or between S2 and overall algal community composition. Thus, they argued against a strong linkage between climate warming, aquatic primary production, and $\mathrm{Hg}$ sedimentation. More recently, Jiang et al. ${ }^{19}$ compared long-term $[\mathrm{Hg}]$ and $\mathrm{Hg}$ accumulation rates with a suite of biogeochemical proxies in a ${ }^{210} \mathrm{~Pb}$ - and ${ }^{14} \mathrm{C}$-dated sediment core from Svalbard. They document a steady increase in $[\mathrm{Hg}]$ and $\mathrm{Hg}$ accumulation rate beginning $\sim 1400 \mathrm{AD}$. This increase occurs despite little change in aquatic paleo-production (as inferred by Rock-Eval analysis, spectrally inferred Chl- $a$, and 

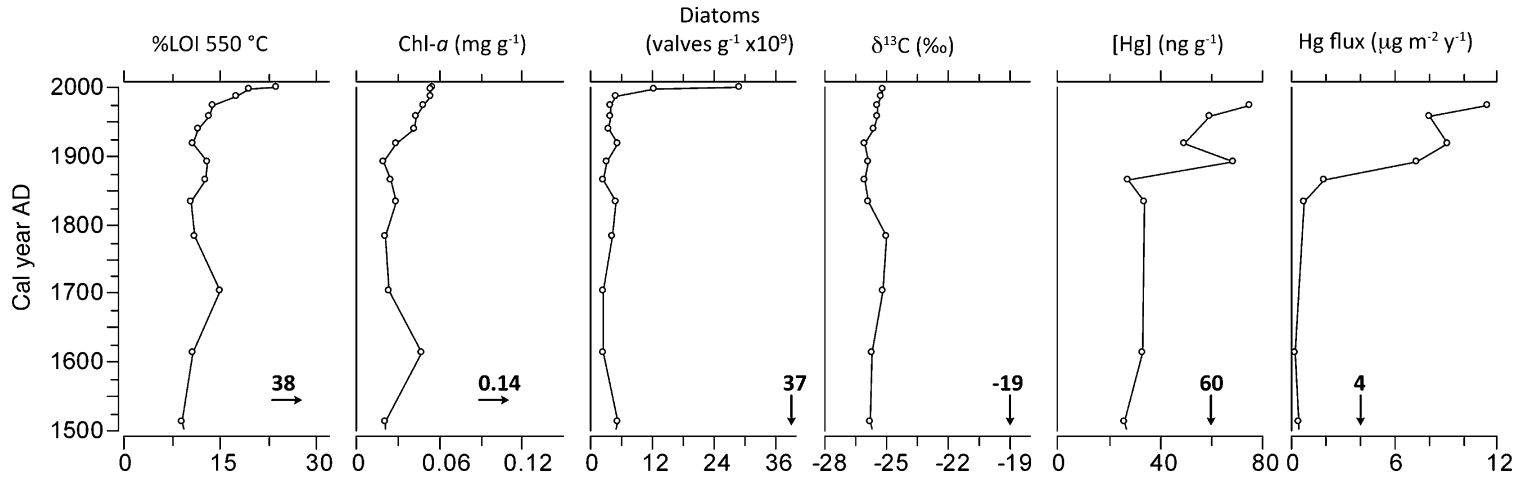

Figure 4. Recent trends within Lake CF3 sediment. Recent data are benchmarked by Holocene (pre-1800 AD) maximum values, which are indicated in bold.

algal pigments). While these authors interpret this increase as recording the long-range transport of early (preindustrial) $\mathrm{Hg}$ emissions, the lack of any coeval increases in other high- and midlatitude lake sediment cores (c.f., refs 7 and 37) suggests otherwise. Instead, parallel increases in total organic carbon and sediment $\mathrm{C} / \mathrm{N}$ ratios $(>20)$ suggest that the export of organicbound $\mathrm{Hg}$ from the catchment to the lake is a more likely cause (Figures 2 and 3 in ref 19). A similar relationship between organic $\mathrm{C}, \mathrm{C} / \mathrm{N}$, and $[\mathrm{Hg}]$ was noted by Wilson et al. ${ }^{38}$ in a sediment core form Lake CF8, a small lake adjacent to CF3 on eastern Baffin Island. The Lake CF8 sediment record preserves organic-rich sediments from three interglacials (marine isotope stages [MIS] 1, 5e, and 7) and one interstadial (MIS 5a or 5c), which collectively span the past $\sim 200000$ years. ${ }^{21,39}$ In Lake $\mathrm{CF} 8,[\mathrm{Hg}]$ was found to covary with both $\mathrm{LOI}$ and $\mathrm{C} / \mathrm{N}$ ratio, but not with either biogenic silica $(\mathrm{BSi})$ or diatom community composition, leading to the conclusion that the input of organic-bound $\mathrm{Hg}$ from the watershed to the lake exerted a first-order conrol over the lake $\mathrm{Hg}$ budget. ${ }^{38}$

The Industrial Era. The uppermost sediment interval for which sufficient material remained for $[\mathrm{Hg}]$ analysis dates to $\sim 1970$ (1.75 cm depth). Between 1500 and $1900 \mathrm{AD}$, there is relatively little change in any of the variables measured (Figure 4). But after $1850 \mathrm{AD}$, both $[\mathrm{Hg}]$ and $\mathrm{Hg}$ flux begin to increase; $[\mathrm{Hg}]$ rises by a factor of 3 , while $\mathrm{Hg}$ flux rises by about an order of magnitude. The increase in both $[\mathrm{Hg}]$ and $\mathrm{Hg}$ flux occur well before any increase in organic matter and diatom concentrations, and $\mathrm{Chl}-a$ and $\delta^{13} \mathrm{C}$ values remain relatively stable, even into the upper-most sediments. The rate of the recent rise in $[\mathrm{Hg}]$ and $\mathrm{Hg}$ flux is also unique in the context of the Holocene. Thus, the balance of evidence suggests that the recent rise in $\mathrm{Hg}$ preserved in CF3 sediments is due to the long-range transport of anthropogenic $\mathrm{Hg}$ from low to high latitudes, as has been inferred from numerous other Arctic and subarctic lake sediment cores (e.g., refs 6 and 7).

Within Lake CF3 sediment, $\mathrm{Hg}$ flux increases to a much greater degree than $[\mathrm{Hg}]$ (Figure 4). A similarly large increase in $\mathrm{Hg}$ flux, relative to $[\mathrm{Hg}]$, has been observed in other Baffin Island lake sediment cores. ${ }^{10}$ Estimates of $\mathrm{Hg}$ flux incorporate $\mathrm{Hg}$ that is delivered to the lake from both the watershed and atmospheric wet and dry deposition. The disproportionately large increase in $\mathrm{Hg}$ flux observed in this and other Baffin Island lake sediment cores is therefore likely amplified by accelerating sedimentation rates. While the current study lacks the geochemical data necessary to make any inferences about catchment-related processes and their influence on lake sedimentation rates (c.f., ref 7), it seems clear that lakes located on the eastern coast of Baffin Island have experienced pronounced increases in the delivery of sediment and associated trace metals over the past century. ${ }^{10,33,40}$

Comparison with Other Lake Records of Long-Term Arctic Hg Accumulation. There has been little prior work examining long-term trends in Arctic $\mathrm{Hg}$ accumulation over the Holocene using well-dated lacustrine sediment cores. A study of three lake sediment cores from the west coast of Greenland ${ }^{41}$ spanning 1000, 4800, and 8000 years, respectively, were analyzed for not only $\mathrm{Hg}$ and $\mathrm{C}$ content, but also $\mathrm{Pb}, \mathrm{Pb}$ stable isotopes, and in the latter two cores, $\mathrm{Ca}$ and $\mathrm{Mg}$ as well. Variable aeoloian influx of glacio-fluvial material (identified using $\mathrm{Pb}$ stable isotopes) resulted in large fluctuations in $\mathrm{Hg}$ and $\mathrm{Pb}{ }^{41}$ While their dating resolution could not allow for the determination of $\mathrm{Hg}$ accumulation rates, all three cores preserved a 3- to 4 -fold increase in $[\mathrm{Hg}]$ since $\sim 1850 \mathrm{AD}$, as observed within CF3 sediment (Figure 4).

Late Holocene $\mathrm{Hg}$ accumulation rates in Arctic lakes appear to have been quite variable. On Baffin Island, $\mathrm{Hg}$ accumulation rates were $<1 \mu \mathrm{g} \mathrm{m}^{-2} \mathrm{y}^{-1}$ immediately prior to the indstrial era (this study and refs 10 and 38). In contrast, late Holocene $\mathrm{Hg}$ accumulation rates within the ${ }^{14} \mathrm{C}$-dated Svalbard sediment core presented by Jiang et al. ${ }^{19}$ average $4.8 \mu \mathrm{g} \mathrm{m}^{-2} \mathrm{y}^{-1}$ (range 3.1$\left.8.6 \mu \mathrm{g} \mathrm{m}^{-2} \mathrm{y}^{-1}\right)$. Muir et al. ${ }^{6}$ used ${ }^{210} \mathrm{~Pb}$-dated sediment cores to estimate early 20th century $\mathrm{Hg}$ accumulation rates in 18 Canadian Arctic lakes. Most of these lakes were characterized by preindustrial $\mathrm{Hg}$ accumulation rates of $\sim 6 \mu \mathrm{g} \mathrm{m}^{-2} \mathrm{y}^{-1}$, after correction for sediment focusing. Among these 18 lakes, the lowest preindustrial $\mathrm{Hg}$ accumulation rate was $\sim 0.5 \mu \mathrm{g} \mathrm{m}^{-2} \mathrm{y}^{-1}$ from Lake CF11, which is located close to both CF3 and CF8 of Wilson et al. ${ }^{38}$ Thus, a consistent picture emerges in which lakes on eastern Baffin Island are characterized by lower late Holocene $\mathrm{Hg}$ accumulation rates relative to most other regions of the Arctic. Climate warming has also greatly accelerated sedimentation rates within these lakes, which, in combination to the long-range atmospheric transport of anthropogenic $\mathrm{Hg}$, seems to be driving recent increases in sediment $\mathrm{Hg}$ (Figure 4).

The algal scavenging hypothesis has generated considerable debate since it was first proposed. ${ }^{11}$ The results presented here provide a further test of this hypothesis both in the presence and absence of anthropogenic emissions. While early Holocene warming led to clear increases in aquatic primary production in Lake CF3, we find no evidence that this led to attendant increases in lake sediment $\mathrm{Hg}$. Over the past $\sim 100$ years, $[\mathrm{Hg}]$ and $\mathrm{Hg}$ flux have also increased in the absence of any coeval increase in aquatic primary production. These observations therefore provide support for the notion that recent increases of 
$\mathrm{Hg}$ recorded in arctic lake sediment cores are primarily due to the long-range transport and deposition of $\mathrm{Hg}$ emitted by anthropogenic activities.

\section{ASSOCIATED CONTENT}

\section{S Supporting Information}

This material is available free of charge via the Internet at http://pubs.acs.org.

\section{AUTHOR INFORMATION}

\section{Corresponding Author}

*E-mail: colin.cooke@yale.edu.

\section{Notes}

The authors declare no competing financial interest.

\section{ACKNOWLEDGMENTS}

We thank Vince St. Louis, Marc Lucotte, four anonymous reviewers, and the journal editor for their valuable comments on earlier drafts of this manuscript. Funding for this research was provided by the Natural Sciences and Engineering Research Council of Canada and the National Geographic Society Committee for Research and Exploration.

\section{REFERENCES}

(1) AMAP. Assessment Report: Arctic Pollution 2002; Arctic Monitoring Assessment Programme: Oslo, Norway, 2002.

(2) Lin, C. J.; Pehkonen, S. O. The chemistry of atmospheric mercury: A review. Atmos. Environ. 1999, 33, 2067-2079.

(3) Slemr, F.; Brunke, E.-G.; Ebinghaus, R.; Temme, C.; Munthe, J.; Wängberg, I.; Schroeder, W. H.; Steffen, A. Worldwide trend of atmospheric mercury since 1977. Geophys. Res. Lett. 2003, 30, 1516.

(4) Braune, B. M.; Outridge, P. M.; Fisk, A. T.; Muir, D. C. G.; Helm, P. A.; Hobbs, K.; Hoekstra, P. F.; Kuzyk, Z. A.; Kwan, M.; Letcher, R. J. Persistent organic pollutants and mercury in marine biota of the Canadian Arctic: An overview of spatial and temporal trends. Sci. Total Environ. 2005, 351, 4-56.

(5) Dietz, R.; Outridge, P. M.; Hobson, K. A. Anthropogenic contributions to mercury levels in present-day Arctic animals-a review. Sci. Total Environ. 2009, 407, 6120-6131.

(6) Muir, D. C. G.; Wang, X.; Yang, F.; Nguyen, N.; Jackson, T. A.; Evans, M. S.; Douglas, M.; Köck, G.; Lamoureux, S.; Pienitz, R.; Smol, J. P.; Vincent, W. F.; Dastoor, A. Spatial trends and historical deposition of mercury in eastern and northern Canada inferred from lake sediment cores. Environ. Sci. Technol. 2009, 43, 4802-4809.

(7) Fitzgerald, W. F.; Engstrom, D. R.; Lamborg, C. H.; Tseng, C. M.; Balcom, P. H.; Hammerschmidt, C. R. Modern and historic atmospheric mercury fluxes in northern Alaska: Global sources and Arctic depletion. Environ. Sci. Technol. 2005, 39, 557-568.

(8) Lockhart, W. L.; Wilkinson, P.; Billeck, B. N.; Danell, R. A.; Hunt, R. V.; Brunskill, G. J.; Delaronde, J.; St. Louis, V. Fluxes of mercury to lake sediments in central and northern Canada inferred from dated sediment cores. Biogeochemistry 1998, 40, 163-173.

(9) Lockhart, W. L.; Wilkinson, P.; Billeck, B. N.; Hunt, R. V.; Wagemann, R.; Brunskill, G. J. Current and historical inputs of mercury to high-latitude lakes in Canada and to Hudson Bay. Water, Air, Soil Pollut. 1995, 80, 603-610.

(10) Cooke, C. A.; Hobbs, W. O.; Michelutti, N.; Wolfe, A. P. Reliance on ${ }^{210} \mathrm{~Pb}$ chronology can compromise the inference of preindustrial $\mathrm{Hg}$ flux to lake sediments. Environ. Sci. Technol. 2010, 44, 1998-2003.

(11) Outridge, P. M.; Sanei, H.; Stern, G. A.; Hamilton, P. B.; Goodarzi, F. Evidence for control of mercury accumulation rates in Canadian High Arctic lake sediments by variations of aquatic primary productivity. Environ. Sci. Technol. 2007, 41, 5259-5265.

(12) Stern, G. A.; Sanei, H.; Roach, P.; DeLaronde, J.; Outridge, P. $M$. Historical interrelated variations of mercury and aquatic organic matter in lake sediment cores from a subarctic lake in Yukon, Canada: Further evidence toward the algal-mercury scavenging hypothesis. Environ. Sci. Technol. 2009, 43, 7684-7690.

(13) Carrie, J.; Wang, F.; Sanei, H.; Macdonald, R. W.; Outridge, P. M.; Stern, G. A. Increasing contaminant burdens in an Arctic fish, burbot (lota lota), in a warming climate. Environ. Sci. Technol. 2009, 44, 316-322.

(14) Sanei, H.; Outridge, P.; Dallimore, A.; Hamilton, P. Mercuryorganic matter relationships in pre-pollution sediments of thermokarst lakes from the Mackenzie River delta, Canada: The role of depositional environment. Biogeochemistry 2010, DOI: 10.1007/ s10533-010-9543-1.

(15) Michelutti, N.; Wolfe, A. P.; Vinebrooke, R. D.; Rivard, B.; Briner, J. P., Recent primary production increases in arctic lakes. Geophys. Res. Lett. 2005, 32.

(16) Kirk, J. L.; Muir, D. C. M.; Antoniades, D.; Douglas, M. S. V.; Evans, M. S.; Jackson, T. A.; Kling, H.; Lamoureux, S.; Lim, D. S. S.; Pienitz, R.; Smol, J. P.; Stewart, K.; Wang, X.; Yang, F. Climate change and mercury accumulation in Canadian high and subarctic lakes. Environ. Sci. Technol. 2011, 45, 964-970.

(17) Outridge, P. M.; Sanei, H.; Stern, G. A.; Goodsite, M.; Hamilton, P. B.; Carrie, J.; Goodarzi, F.; Macdonald, R. W. Comment on climate change and mercury accumulation in Canadian high and subarctic lakes. Environ. Sci. Technol. 2011, 45, 6703-6704.

(18) Kirk, J. L.; Muir, D. C. G.; Antoniades, D.; Douglas, M. S. V.; Evans, M. S.; Jackson, T. A.; Kling, H.; Lamoureux, S.; Lim, D. S. S.; Pienitz, R.; Smol, J. P.; Stewart, K.; Wang, X.; Yang, F. Response to comment on climate change and mercury accumulation in Canadian high and subarctic lakes. Environ. Sci. Technol. 2011, 45, 6705-6706.

(19) Jiang, S.; Liu, X.; Chen, Q. Distribution of total mercury and methylmercury in lake sediments in Aarctic Ny-Ålesund. Chemosphere 2011, 83, 1108-1116.

(20) Wolfe, A. P.; Smith, I. R., Paleolimnology of the canadian arctic archipelago. In Long-Term Environmental Change in Arctic and Antarctic Lakes. Developments in Paleoenvironmental Research, Pienitz, R.; Douglas, M. S. V., Smol, J. P., Eds.; Springer: Dordrecht, 2004; Vol. 8 , pp 241-268.

(21) Axford, Y.; Briner, J. P.; Cooke, C. A.; Francis, D. R.; Michelutti, N.; Miller, G. H.; Smol, J. P.; Thomas, E. K.; Wilson, C. R.; Wolfe, A. $\mathrm{P}$. Recent changes in a remote Arctic lake are unique within the past 200,000 years. Proc. Natl. Acad. Sci. 2009, 106, 18443-18446.

(22) Axford, Y.; Briner, J. P.; Miller, G. H.; Francis, D. R. Paleoecological evidence for abrupt cold reversals during peak Holocene warmth on Baffin Island, Arctic Canada. Quat. Res. 2009, $71,142-149$.

(23) Briner, J. P.; Michelutti, N.; Francis, D. R.; Miller, G. H.; Axford, Y.; Wooller, M. J.; Wolfe, A. P. A multi-proxy lacustrine record of Holocene climate change on northeastern Baffin Island, Arctic Canada. Quat. Res. 2006, 65, 431-442.

(24) Fisher, D. A.; Koerner, R. M.; Reeh, N., Holocene climate records from the Aagassiz Ice Cap, Ellesmere Island, NWT, Canada. Holocene 1995, 5 .

(25) Dyke, A. S.; Hooper, J.; Savelle, J. M. A history of sea ice in the Canadian arctic archipelago based on postglacial remains of the bowhead whale (Balaena mysticetus). Arctic 1996, 49, 235-255.

(26) Michelutti, N.; Wolfe, A. P.; Briner, J. P.; Miller, G. H., Climatically controlled chemical and biological development in arctic lakes. J. Geophys. Res. 2007, 112.

(27) Glew, J. R.; Smol, J. P.; Last, W. M., Sediment core collection and extrusion. In Tracking Environmental Change Using Lake Sediments: Basin Analysis, Coring, And Chronological Techniques, Last, W., Smol, J. P., Eds. Springer: New York, 2001; pp 73-105.

(28) Nesje, A. A piston corer for lacustrine and marine sediments. Arct. Alp. Res. 1992, 24, 257-259.

(29) Wolfe, A. P.; Miller, G. H.; Olsen, C. A.; Forman, S. L.; Doran, P. T.; Holmgren, S. U., Geochronology of high latitude lake sediments. In Long-Term Environmental Change in Arctic and Antarctic Lakes; Pienitz, R., Douglas, M. S. V., Smol, J. P., Eds.; Kluwer Academic Publishers: Dordrecht, The Netherlands, 2004; pp 19-52. 
(30) EPA Mercury in Solids and Solutions by Thermal Decomposition, Amalgamation, And Atomic Absorption Spectrophotometry; Environmental Protection Agency: Washington, DC, 1998.

(31) Wolfe, A. P.; Vinebrooke, R.; Michelutti, N.; Rivard, B.; Das, B. Experimental calibration of lake-sediment spectral reflectance to chlorophyll a concentrations: Methodology and paleolimnological validation. J. Paleolimnol. 2006, 36, 91-100.

(32) Blaauw, M. Methods and code for 'classical' age-modelling of radiocarbon sequences. Quat. Geochron. 2010, 5, 512-518.

(33) Thomas, E. K.; Axford, Y.; Briner, J. P. Rapid 20th century environmental change on northeastern Baffin Island, Arctic Canada inferred from a multi-proxy lacustrine record. J. Paleolimnol. 2008, 40, 507-517.

(34) Benoy, G. A.; Kalff, J. Sediment accumulation and Pb burdens in submerged macrophyte beds. Limnol. Oceanogr. 1999, 44, 1081-1090.

(35) Schelske, C. L.; Hodell, D. A. Using carbon isotopes of bulk sedimentary organic matter to reconstruct the history of nutrient loading and eutrophication in Lake Erie. Limnol. Oceanogr. 1995, 40, 918-929.

(36) Wooller, M. J.; Francis, D.; Fogel, M. L.; Miller, G. H.; Walker, I. R.; Wolfe, A. P. Quantitative paleotemperature estimates from $\delta^{18} \mathrm{O}$ of chironomid head capsules preserved in Arctic lake sediments. J. Paleolimnol. 2004, 31, 267-274.

(37) Lamborg, C. H.; Fitzgerald, W. F.; Damman, A. W. H.; Benoit, J. M.; Balcom, P. H.; Engstrom, D. R. Modern and historic atmospheric mercury fluxes in both hemispheres: Global and regional mercury cycling implications. Global Biogeochem. Cycles 2002, 16, 1104.

(38) Wilson, C. R.; Michelutti, N.; Cooke, C. A.; Briner, J. P.; Wolfe, A. P.; Smol, J. P. Arctic lake ontogeny across multiple interglaciations. Quat. Sci. Rev. 2012, 31, 112-126.

(39) Briner, J. P.; Axford, Y.; Forman, S. L.; Miller, G. H.; Wolfe, A. P. Multiple generations of interglacial lake sediment preserved beneath the laurentide ice sheet. Geology 2007, 35, 887-890.

(40) Michelutti, N.; Simonetti, A.; Briner, J. P.; Funder, S.; Creaser, R. A.; Wolfe, A. P. Temporal trends of pollution $\mathrm{Pb}$ and other metals in east-central Baffin Island inferred from lake sediment geochemistry. Sci. Total Environ. 2009, 407, 5653-5662.

(41) Lindeberg, C.; Bindler, R.; Renberg, I.; Emteryd, O.; Karlsson, E.; Anderson, N. J. Natural fluctuations of mercury and lead in greenland lake sediments. Environ. Sci. Technol. 2006, 40, 90-95.

(42) Berger, A.; Loutre, M. F. Insolation values for the climate of the last 10 million years. Quat. Sci. Rev. 1991, 10, 297-317. 